\title{
THE IMPLEMENTATION OF SELF EVALUATION TEACHER TALK (SETT) IN TEACHING ENGLISH: A CASE STUDY
}

\author{
Raden Panji Hartono, raden.17070835054@mhs.unesa.ac.id, Universitas Negeri \\ Surabaya, Indonesia \\ Slamet Setiawan, Ph. D, slametsetiawan@unesa.ac.id, Universitas Negeri \\ Surabaya, Indonesia \\ Dr. Maria Mintowati, M.Pd, mintowati@unesa.ac.id, Universitas Negeri \\ Surabaya, Indonesia
}

\begin{abstract}
This study analyzed the implementation of SETT (Self Evaluation Teacher Talk) (Walsh, 2011) by an English teacher in a senior high school in Surabaya. A descriptive analysis was conducted towards the talk used by teacher in delivering the material. As the law, the teacher regulated the students to speak the target language anyhow. On the other hand, the teacher applied a classroom interaction in English. There are four modes available based on the SETT criteria; managerial mode, material mode, skill and system mode, classroom context mode. The result shown that the teacher mostly applied two mode, namely managerial mode and skill and system mode, and was followed by classroom context mode, then material mode.
\end{abstract}

Keywords: teacher talk, classroom interaction, SETT (Self Evaluation Teacher Talk)

\section{INTRODUCTION}

Communication in the field of foreign or second language context is a complicated phenomenon which is being the central to the classroom activities. The interaction between teacher and students is the key toward the success or failure of learning a foreign or second language. Van Lier (1996, cited in Walsh, 2006) argues that if a foreign language teacher expects an effective interaction, then the interaction should be well considered as the most important thing in the teaching foreign or second language acquisition curriculum. An effective teacher talk should try to improve the foreign or second language classroom and to promote learners for doing it. At any rate, teacher should serve the objectives in a common language and let the students get acquaintance with the language, promoting genuine learning through interaction (Noni, 1994:1).

There are many ways in which teachers can construct students participation in interpersonal, or commonly called as face to face classroom interaction through their choice of language (Walsh, 2002). The awareness of the teacher minds their interaction quality that would determine the effective learning. As Walsh (2006) suggests that an awareness of the interactional process help teacher and learners to have a comprehensive understanding of how language is acquired.

The spoken language which are being used called as teacher talk. Teacher talk is used to manifest and share knowledge for the students. There are three things guiding teacher to do teacher

216 | IJET| Volume. 10, Issue 2. December 2021

Copyright 2021 Raden Panji Hartono, Slamet Setiawan, and Maria Mintowati are licensed under Creative Commons Atrribution-ShareAlike 4.0 International License. 
talk; (a) elicit relevant knowledge from students; so that teacher choose a proper word to convey the knowledge as it has already known by the students as well; (b) respond to things that students say; a feedback towards students respond should be attempted by incorporations into the flow of discourse meaning by the students; (c) describe the classroom experiences that they share with students in such a way that the educational significance of those joint experiences is revealed and emphasized (Mercer, 1995:25).

By hence, knowing that teacher talk for the learner is potentially becomes valuable source of comprehensible input which is viewed necessary for language acquisition (Cullen, 1998:179), then there should be awareness from the teacher towards the fluency of their speech, how much the teacher talk, and what a meaningful talk need to be performed in an effective way. The same suggested by Lei (2009) that good teacher talk focused on how the teacher effectively promote genuine communication in the classroom.

At any rate, teacher should serve the objectives in a common language and let the students get acquaintance with the language, promoting genuine learning through interaction (Noni, 1994:1). In addition, a constructive communicational is essential in building students' motivation to speak the target language. As Setiawati (2012) suggested that the use of constructive teacher talk is vital and effective for learners to improve their skill in target language. Coultas (2009) added that constructive talk is an essential ingredients of a good lesson, a vital part to engage student with their learning, an instrument to transform relationships.

In attempting the effectiveness of teacher's talk, consequently the quality of the teacher talk is also consider important to give chance for the students to develop and perform the language by interaction. As a matter of fact, the teaching and learning process should be able to grab students' attention especially they can predict what they will learn and express the target language. As Brown (2001:168) stated that interactive teaching is to strive against the upper, non-directive end of the continuum, gradually enabling the students to move their roles from total dependent to relatively total independent.

Teachers should function their talk as "central point" to gain effective teaching and learning process (Vygotsky, 1978). Wood as cited in Cameron (2001 pp. 8-9) added that teacher talk is very effective in scaffolding learners in various ways. Thus, teacher should manage their talk in a meaningful way, and might use repetitions on key language if it eventually needed and modify the language to make it easier to be understood.

Even so, the term of talk in language classroom is still leave question toward what talk should be applied, since the goal of language teaching is students can produce the target language, a teacher is to be keen on to be creatively establish an enthusiastic teaching learning through the language which being used. Cullen (2002) investigated some aspects of teacher talk that is teacher's feedback toward students' responses, examined the target language (second language) by role it plays. Contrary, since the existence of second language is learner is asking to practice it directly in spoken, Mercer (2000), Mulyati (2013) and Nuraini \& Hamim (2015), shown in their research that the teacher spent more time talking during the second language process. Hence, it seems that "the students had failed for the lesson. According to Dudley-Evans and St Jones (1998) stated that apart from the main tasks of English teacher generally is to controlling ongoing classroom activities, providing information about skills and language and organizing pair- or group work.

In fact that teacher talk and its teaching foreign/second language classroom had been under researched by Flanders (1970) and Moskowitz (1971). FIAC (Flanders Interaction Analysis Categories) by Flanders is addressed to be used in classroom language. In responding the foreign language interaction analysis models designed by Flanders (1970), Walsh (2006:42) claims that the Flander's categories are rather broad and still leave questionably in a certain complexity interactional organization of the contemporary classroom. Walsh (2006:42) in responding Flint 
(Foreign Language INTeraction) by Moskowitsz (1971), is thought more sophisticated and more complex than the original Flanders system.

Since those categories proposed to analyze the interactional models during the foreign or second language teaching by the teacher, Seedhouse (1996:23) suggested to concentrate on the characteristic features which related to the institutional discourse. SETT (Self Evaluation of Teacher Talk) as the new revision by Walsh (2011) offers a new approach in helping teacher to develop their teacher talk (interactional features) and to be aware to its pedagogic goal. SETT is set up to gain more information against teacher talk, knowing the pivotal role of teacher talk in the classroom which highly related to teacher's pedagogy and the language being used by the teacher varies according to pedagogic purpose at certain point. As Walsh (2002) stated Since pedagogy and interaction stand along during the teaching and learning, then learning opportunity is facilitated; oppositely, since the language use and teaching goal experience deviation, then the opportunity for learning are missed. The gap relies on the different of the instrument where Wasi'ah (2017) used the old one by Walsh (2006) and this present study claims that the revised one by Walsh (2011) will provide different additional knowledge by also knowing the purpose of why the talk is used. This study correlates the teacher talk to seek the line with the pedagogical goal during the teaching and learning is occuring.

\section{METHOD}

This study applied qualitatively to explore and understand the meaning individuals or groups ascribe to a social or human problem. Since teacher's talk come up with interaction among students, then this study aims to investigate the interactional features and how it fits with the teacher's aim (pedagogic goal) to use certain talk. The data collected during the teaching and learning process occurring naturally. An English teacher with his students selected to participate in this study. She applied English classroom interaction in the English language learning. The participants of this study are the second grade students of XI-5 who has good records in academical score, especially in English lesson.

The data present in this study were collected through observation and interview. By doing observation, the teacher talk (utterances) and the students' responses being recorded through video and audio. The recording is starting from the teacher begins the class. The data form are in words, phrases, and sentences. It takes during the teacher starts the teaching until the end of the class. After gathering the data, then operating it into Walsh's (2011) model, they were analyzed based on the principles of SETT. The interview was used to collect unseen data through the observation and in charge of data cross checking. The data cross checking means, as to make sure that the data obtained through the observation were valid by re-asking to the teacher. The questions were openended questions. It was around the teacher experiences and as confirmation check why was something happened and done.

\section{RESULT}

Class XI-5 SMA Negeri 15 was taken to be analyzed. One female teacher has been observed, as the English teacher. She has been in charged of as an English teacher for more than 15 years. Through the interview, she said that to be mastered English, she believed that the implementation of classroom interaction in the target language has its own value in establishing students' competences and skill. She added that as the existence of language is to be spoken, then a refraction to speak the target language during the teacher and learning process was an obligation. Under her controlling, the students should answer or ask in English.

219 | IJET $\mid$ Volume. 10, Issue 2. December 2021

Copyright 2021 Raden Panji Hartono, Slamet Setiawan, and Maria Mintowati are licensed under Creative Commons Atrribution-ShareAlike 4.0 International License. 
The students in XI-5 are consisted of 36; 14 males and 22 females. The seating arrangement is in lockstep mode. The teaching and learning process took 90 minutes (one hour and a half). The teacher applied a media to deliver the material, namely power point text. It was expected to grab the students' mood and attention through the media. Second, this could be such as an effective way to not write on the white board and to keep focus talking by moving from one slide to another slide.

The data obtained from the observation sheet, it was found that the teacher applied all of the modes of SETT by Walsh (2011). The data gained that the teacher applied mostly managerial mode and skill and system mode rather than the two another modes. It was shown after the coding and categorizing the transcription into the SETT mode's criteria (managerial mode, material mode, skill and system mode, classroom context mode). Managerial mode and skill and system have 7 columns (based on their categorize). From the managerial mode, it was dominated by the using of transitional markers (and then, next, the first, second, now, etc) in transmitting the information and or introduce the learning. As the term managerial which is to manage, the teacher used such an instruction of physical moving management only in the post-teaching. The physical moving management was used as an instruction to make a group and performance task for further. And then, it was followed by classroom context with 6 of its column, and the last material mode with 2 of its column.

As the entire criteria has categorized based on the SETT (Self Evaluation Teacher Talk) by Walsh (2011), here for more explanation are discussed as follow:

\section{Teacher's Interaction Analysis based on SETT frame work.}

As to answer the first question in this study, the entire interaction is categorized based on the SETT mode: (a) managerial mode, (b) material mode, (c) skill and system mode and (d) classroom context mode.

\section{a. Managerial mode}

This mode encompassed how the teaching and learning were applied through the talk. The talk that are purposed to transmit information, managing the physical learning, refer to the material, introduce or conclude an activity, changing from one mode to another mode. In transmitting the information, and move to certain topic or question, the teacher mostly used transitional markers (and then, next, first, second, the last, now, etc). It was confirmed by the teacher that she purposefully used those transitional markers as a gap into next utterance, and addressed the students to understand step by step. Here an example was taken from the transcription as follow:

31) T : Okay, good. Next, here other learning objectives for today's learning, the first is, analysing language features of analytical exposistion sentence, second, understanding the structure of an analytical exposition text, understanding the language features of an analytical exposition text, and then finding and arranging the jumble sentences of an analytical exposition text, and the last is reading the analytical exposition loudly in front of the class with correct pronunciation and stressing. (Teacher shows a short video about smoking)

The transitional markers above help the teacher to give a sign as a gap and move to another question or topic. The word next plays as a sign that the topic before has over and out and moves to another introduction. This commonly happened almost in the beginning or end during the teaching and 
learning process. Another transitional markers found was the first. This can be seen directly after the teacher done from telling that now today's learning was different. This the first shown how the teacher was trying to tell what were going to learn at that moment through steps. It means, the first the followed by another transitional markers like second, and then, and the last as signs to show the steps.

Furthermore, based on the example above, another function of managerial mode was to refer the learners to the material. Unconciously, the using of those transitional markers led the students to be more aware towards the topic they learn. This is one of the point mentioned in the pedagogic goal as the goal-oriented which to refer to the material. As the term is managerial, there should be a moving during the teaching and learning process in the form of physical management. Here was another example of managerial mode used by the teacher taken from the transcription:

101)T : Okay, and next is the generic structure of analytical exposition. The first, yaa, thesis yaa, introduces the topic indicated an arguments. Arguments, means that there are, of course more than one arguments ya, argument one two three, and the last one is conclusion. Next, the language features of analytical exposition, they used simple present tense, and then connectors, firstly secondly and others. And the last one is to summarize at the last pharagraph, summarizing or concluding. Okay now, the danger of smoking. Here are some jumble pharagraph, what you have to do is, you have to rearrange into a good order, and here i would like you to make a group of four students and after you have to present and give your opinion why are you choose that arrangement. And the next, another group gives question about it. Okay? so, would you please make a group of four?

102)Ss : :-students are beginning to find their group and starting to discuss-

The interaction above, at the very first utterance, it shown that how the teacher dominated to give a long talk rather than provide a chance to talk for the students. This is called as an extended teacher turn where the teacher decided to explain first the material given. Since the material was finished to be explained, then it came up with the physical moving management. The teacher instructed the students to be separated into some groups. It shown from the instruction, "........and here $i$ would like you to make a group of four students...". this utterance holds its role in managerial mode as the pivotal point how this mode is established. The teacher claimed that the using this group discussion would help them in sharing and exploring their ideas around the topic given.

However, as the matter of fact, the utterance which were following the instruction ("......and after that you have to present and give your opinion why are you choose that arrangement. And the next, another group gives question about it...." ) were not included as the physical moving instruction, but as the extended teacher turn to make the instruction clearly understood by the students.

\section{b. Material Mode}

This material mode comes out by the term material. It deals with how the material is discussed during the teaching and learning process. The teacher afforded to around the discussion with the material. The interaction are merely question, answer session which are encompassed in the IRF context. The interaction is closely managed by the teacher to avoid unexpected response from the students. 
However, to avoid the unexpected response from the students are merely to keep focus and aware towards the topic discussed. In overcoming this case, direct repair, giving feedback straightly, intteruption from the teacher are allowed for the teacher. This is relating to evaluate the students contribution while giving response during the teaching and learning process. In addition, since this case probably happen, this is also addressing to scaffold students contribution. So then, the students may re-think, re-explore, and provide another answer after obtained feedback from the teacher.

However, this example below shown how the students were giving well and correct responses after the teacher prompted them onto certain questions:

22) T : and then next (moving to next slide), now, what is the topic of the video? What is it about?

23) Ss : the causes if we are smoking.

24) $\mathrm{T}$ : okay, the causes if we are smoking. How about the other? But, the causes or the effect?

25) Ss : : effect...

26) $\mathrm{T} \quad$ : Yeaaaaaa... and then what are the terrible things happen to your body? Mention them.

27) $\mathrm{S} \quad$ : Increases the potential of stroke

28) T : okay. Number two? Who wants to answer?

29) $\mathrm{S}$ : encourage cancer.

30) $\mathrm{T} \quad$ : okay number three?

31) $\mathrm{S} \quad$ : destroys our lung

32) T : destroys our lung. Okay then?

33) $\mathrm{S} \quad$ : thicken the blood.

34) T : thicken the blood. Okay, and then next? Is that all?

35) Ss : Increase the bad breath.

36) $\mathrm{T}$ : Good, increase the bad breath. What else? Is it the last one?

37) Ss : NO

38) $\mathrm{T} \quad$ : You still have ?

39) Ss : : Four.

40) $\mathrm{T} \quad$ : four, okay. Raise your hand. Okay, mention all.

41) S : increase the visibility of aging, breaks the immune system, sama apa yaa? (what else in English)

42) $\mathrm{T} \quad$ : how about the last?

43) $\mathrm{S}$ : Cataract.

44) T : Cataract. Okay. Give applause....

The interaction was opened after the teacher done in giving a short video about smoking. Several questions were given around the video. The students only answered based on points which are mentioned in the video, likely the effects of smoking. So, here the question and answer are around several points on the short video to provide language practice towards the material. It was confirmed through the interview by the teacher that first of all, some questions towards the video are given to check their understanding and memorizing. As the effect of smoking mentioned in the video, the teacher are a bit leading the students into re-thinking towards the teaching objective, namely to speak up. 
As the interaction above transcibed, after the students done in answering the first question from the teacher, but the teacher felt a bit strange when the students answered "the causes of smoking". Here, in material mode, teacher holds their responsibility to sometimes give feedback, or scaffold method to obtain corrective feedback from the students. It can be seen in the interaction as follow:

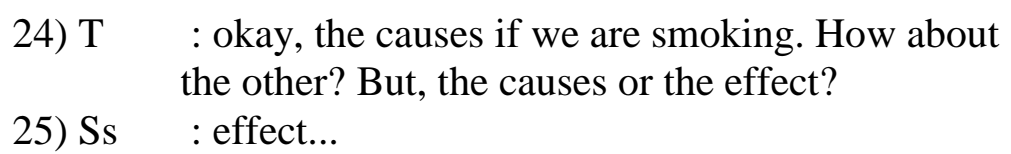

This might be seen as a simple problem which is truly incorrect. The word cause and effect are differentiated each other. The cause is something or someone that produce an effect, result, or condition; something or someone that makes something happen or exist, while effect is the result of something has happened. Fortunately, the teacher was perceptively in responding their response. The question given by the teacher is categorized as display question to check the students comprehension toward what they learnt and answered. It also included as scaffold method to avoide the same errors for another questions.

However, following how the teacher perceptively responded to the students anwer, she was sometimes repeated the student(-s)' answer to support their argument, answer, or opinion that what they said was correct. This is how the IRF shows managed by the teacher through the direct support in replacing their answer. It can be seen as follow:
14) $\mathrm{T} \quad$ : Right, do you still remember the title of this video?
15) Ss : : -mumming....-
16) $\mathrm{T} \quad$ : Yes, raise your hand please! The title, what is it? (points someone)
17) $\mathrm{S} \quad$ : The terrible things.....
18) $\mathrm{T} \quad$ : The terrible things.......
19) $\mathrm{S} \quad$ : of smoking due to your body.
20) $\mathrm{T} \quad$ : due to your body. Okay give applause to your friend.
21) Ss : : (give applause)

From the interaction above, while the teacher known that the students a bit hesitate to answer, she supported the students by pointed them out. Since the student afforded to answer in several words ( $\mathrm{S}:$ the terrible things....), it was followed by the teacher in replacing their answer as the same. So that, it embraced to the student's motivation to explicitely say the answer.

\section{c. Skill and System Mode}

This skill and system mode is to measure the students' understanding by freely revealing their arguments, ideas, opinion, and so forth in the target language. What makes this mode different with material mode is that, this mode is not relies on the answer provide from the topic given. The students literally impropted by the teacher to produce the target language somehow. This mode is to see how the students are trying too manipulate the target language from the students' vocabulary mastery through speak it out loud. This example below is taken from the transcription:

70) $\mathrm{T} \quad$ : Then, can you guess where is it?

71) Ss : Jakarta

72) T : Jakarta? Why is it in Jakarta? Is it in Indonesia?

73) Ss : Noooooooo.

223 | IJET| Volume. 10, Issue 2. December 2021

Copyright 2021 Raden Panji Hartono, Slamet Setiawan, and Maria Mintowati are licensed under Creative Commons Atrribution-ShareAlike 4.0 International License. 


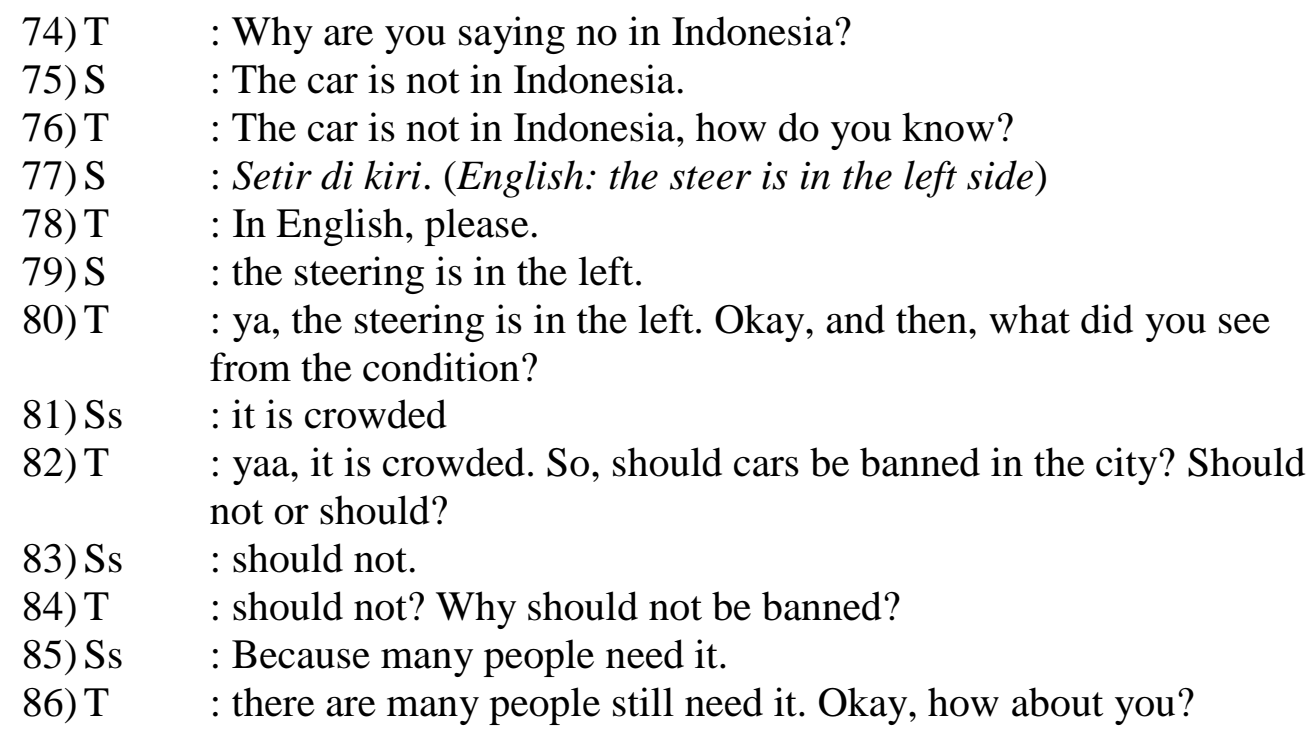

This interaction happened while the teacher was asking for their arguments towards a picture given through the media. The picture depicted a crowded road by cars. The teacher tried to obtain their arguments by extending the question, so that the students more genuinely engaged to answer. It was seen how the IRF in English managed by the teacher resulted a good turn-taking with the students.

However, the student sometimes spoke their native language (mother tongue) to respond the question given a fast way. But, a directly cutting was given to follow the rules to speak the target language. Since this cutting was given, the student was firm enough to speak the target language while the rest were enthusiasm responding to the picture displayed.

In addition, the media helped the teacher to obtain students' responses. A clarification request were applied by the teacher once in a while during the interaction. It purposed to let the students more aware towards what they said. Second, the using of clarification requests in certain interaction (why is it in Jakarta?, is it in Indonesia?, why are you saying no in Indonesia?, how do you know?, should not or should?, why should not be banned) helped the teacher to obtain corrective feedback from the students. In the sequence of clarification request, it led them to the final argument eventually. Last but not least, the turn-taking existed as to show teacher's responsibility in managing the IRF context which was to lead to the learning objective.

\section{d. Classroom Context}

This classroom context emphasized to the external factors right after the teaching and learning process. If skill and system mode is to drill students to manipulate the target language, obtain correct pronunciation or utterances, and any other practice in essential, this classroom context is to let the students reveal their feeling, thought, notion, belief, emotions, experience, reaction and personal relationship. This is commonly given at the beginning or end of the class as to sum up or conclude what they learnt. The task might be in written or spoken.

Furthermore, from the term of classroom context, this is to establish and convince what they learnt. As in the end timing location, apparently scaffolding again is used to measure the students' understanding. As Walsh stated that the use of scaffolding is to establish a context, shape students' comprehension and to provide more acceptabe answer or response. In this interaction below, it can be sen how the performance instruction to conclude was given and the students responded in spoken form: 
138) $\mathrm{T} \quad$ : Based on this text, would you please make the conclusion of that topic. Come one, for each group. You! (points out group)

139) G4 : So, the conclusion of smoking is, yes smoke is may be some people taking as relaxing or enjoying us, but what it really do is truly affect the negative side. And it can make you get skinnier and other by getting all these diseases, smoking is very bad and doesn't have positive side. That's from our group, and thank you.

140) Gs : -give applause-

141) $\mathrm{T} \quad$ : Now, your group (points out group)

142) G5 : The conlusion is smoking is danger for our health and there are also many negative impacts which is not only for us but all people around us. Thank you.

note : ${ }^{*} \mathrm{~T}$ : teacher, ${ }^{*} \mathrm{G}$ : group, ${ }^{*} \mathrm{Gs}$ : entire group

The interaction above happened right before the teacher end up the teaching. The topic still was around "the effects of smoking". The students have approximately five minutes to sum up what they learnt and perform it as well. This performance assessment was to see their view, emotional, experience, belief, and notion towards the topic. In addition, it was also confirmed that the teacher preferred to use performance task as a mean to encourage the students more to elaborate their thinking, view, or ideas in English.

Furthermore, during the students' performance, teacher hold less interaction by letting the extended students' turn. She argued that beside the times was limited, she also claimed that it is acceptable since the message they gave are in accordance with the topic and reasonable. In following the statement, it was confirmed also that the teaching objective was successfully reached after the implementation of those mode (managerial, material, skill and system, and classroom context).

\section{CONCLUSION}

To conclude, during the teaching and learning process, it was found that the teacher applied mostly managerial mode and skill and system mode based on SETT proposed by Walsh (2011). It was followed then by classroom context and the last was material modes. All of these modes have their own contributions helped the teacher to reach the teaching objective, which was enable the students to analyze a text, namely analytical exposition. Since the students were considered understood enough, then a task was given to be delivered in spoken form through performance.

In introducing the material in (managerial mode), the using of transitonal markers (next, and then/then, now, after that, first, second, etc) dominated and helped the teacher to deliver the material step by step. It resulted well contribution from the students. Those are to transmit information and to refer the students to the material. Confirmation check were sometimes used by the teacher to make sure that the students understand and to continue to another part of the topic.

To highlight, it was found in some parts that the modes; (a)managerial, (b)material, (c)skill and system, (d)classroom context) are related each other. For example, an instruction to make a group was given 15 minutes before ended up the class. The students need to perform their arguments toward the topic. This movement was included as managerial mode. But, in the implementation, the seating arrangement from lockstep into group was given before the class ended 
and the students were only have five minutes to perform it not far from the instruction given. The performance was to measure and know the students' ability in delivering their arguments (feeling, emotions, thought, ideas, experience, attitude, and belief) through the target language, which were included as classroom context points. Again, as the teacher set the interaction must be in English, the using of confirmation check and clarification request were also sometimes given by the teacher. These two things are stated in managerial mode and material mode as well to check students comprehension, obtain corrective feedback from the students, even to extend their contributions. The relation between skill and system mode and classroom context were also found from the interaction. Since the teacher instructed the students to do their arguments in spoken form, it was to enable students to manipulate the target language which was stated in skill and system mode. It means, the students are freely deliver their message based on their vocabulary master in English.

By hence, the implementation of this SETT (Self Evaluation Teacher Talk) proposed by Walsh (2011) has its own beneficial for the teacher to reach the teaching objective. Second, need to be underlined that the implementation of this classroom interaction in the target language somehow should more consider the students' ability, or any other students' proficiency level. 


\section{References}

Brown, H. Douglas. 2001. Teaching by Principles; An interactive Approach to Language Pedagogy. New York: Person Education.

Brown, K., \& Kennedy, H. 2011. Learning through Conversation and Extending Teacher and Children's Involvement in Classroom Talk.

London:School Psychology International

Cullen, Richard. 1998. Teacher Talk and the Classroom Context. English Language Teaching Journal Vol. 25 No.3, 179-187.

Dudley-Evans, T., \& St John, M. J. 1998. Developments in ESP. A Multidisciplinary Approach. Cambridge: Cambridge University Press.

Ellis, Rod. 1994. The Study of Second Language Acquisition (Oxford Applied Linguistic). New York: Oxford University Press.

Harmer, Jeremy. 2007. The Practice of English Language Teaching. Edingburgh: Pearson Education Limited.

Krashen, Stephen D. 1981. Second Language Acquisition and Second Language Learning. California. Pergamon Press Inc.

Krashen, Stephen D. 1982. Principles and Practice in Second Langauge Acquisition. California: Pergamon Press Inc.

Kumaravadivelu, B. (1999) 'Critical classroom discourse analysis', TESOL Quarterly, 33: 453-84.

Seedhouse, Paul. 1996. Classroom Interaction: Possibilities and Impossibilities. English Language Teaching Journal Vol. 50 No.1

Mercer, Neil. 1995. The Guided Construction of Knowledge: Talk Amongst Teachers and Learners. Clevedon: Multilingual Matters.

Nunan, D. (1989). Designing tasks for the communicative classroom. Cambridge: Cambridge University Press. University

Nunan, D. 1991. Language Teaching Methodology. Sydney: Macquarie

Nunan, D. (1992). Research Methods in Language Learning. Cambridge: Cambridge University Press.

Nuraini, K., and Hamim, M. 2015. Teacher Talk in Vocational High School Context "Does it Matter?”. Muhammadiyah University of Malang, Malang

Setiawati, Liani. 2012. A Descriptive Study on Teacher Talk at EYL Classroom. Indonesian Journal of Applied Linguistics, Vol. 1 No. 2

Shamsipour, Anahita. 2012. Teacher Talk and Learner Involvement in EFL Classroom: The Case of Iranian Setting. Theory and Practice in Language Studies, Vol. 2, No. 11, pp. 2262-2268

Walsh, Steve. 2002. Construction or Obstruction: Teacher Talk and Learner Improvement in the EFL Classroom. Language Teaching Research Vol. 6 No. 1, 3-23

Van Lier, L. (1996). Interaction in the language curriculum: Awareness, autonomy and authenticity. New York: Longman.

Walsh, Steve. 2006. Investigating Classroom Discourse. New York. Routledge. 
Walsh, Steve. 2011. Exploring Classroom Discourse: Language in Action. New York: Routledge.

3 | IJET| Volume. 10, Issue 2. December 2021 